\title{
Growth and metal uptake of microalgae produced using salt groundwaters from the Bay of Bourgneuf
}

\author{
Sindy Gagneux-Moreaux ${ }^{1, a}$, Richard P. Cosson ${ }^{1}$, Paco Bustamante $^{2}$ and Christophe Moreau ${ }^{1}$ \\ ${ }^{1}$ Université de Nantes, Nantes Atlantique Universités, EMI, EA 2663, ISOMer-UFR Sciences, BP 92208, 44322 Nantes Cedex 3, France \\ 2 Centre de Recherches sur les Ecosystèmes Littoraux Anthropisés, UMR 6217 CNRS-IFREMER-Université de La Rochelle, 22 avenue \\ Michel Crépeau, 17042 La Rochelle, France
}

Received 30 March 2006; Accepted 5 September 2006

\begin{abstract}
The Bay of Bourgneuf, France, is a main site of shellfish production. In the marshes along the bay, oyster intensive rearing and fattening need the mass production of microalgae. Salt groundwaters, available in this region, support a large part of this production for aquaculture. Studies carried out by local authorities have brought to the fore the accumulation of lead $(\mathrm{Pb})$ in several samples of algal pastes derived from cultures using salt groundwater. The aim of this study was to compare growth, nutritional value and metal $(\mathrm{Cd}, \mathrm{Cu}, \mathrm{Pb}$ and $\mathrm{Zn})$ uptake of four microalgae grown in two salt groundwaters or in enriched coastal seawater. Cultures of microalgae used in aquaculture (Haslea ostrearia, Phaeodactylum tricornutum, Skeletonema costatum and Tetraselmis suecica) were realised at the laboratory under controlled experimental conditions. Results indicated that salt groundwaters provided cultures with, at least, an equal biomass and a nutritional value similar to cultures grown in enriched seawater. There was no difference regarding metal accumulation whatever the culture medium, except when $S$. costatum was grown in one of the salt groundwater in which case its cadmium levels were higher and could be above the French guideline level. These observations questioned on the bioavailability of metals in salt groundwaters. It also underlines the specificity of metal uptake and accumulation by microalgae.
\end{abstract}

Key words: Saline groundwater / Trace elements / Bioaccumulation / Diatom / Bacillariophycea / Prasinophycea / Growth / Metals / Aquaculture / Marine microalgae cultivation

\begin{abstract}
Résumé - Croissance et accumulation des métaux chez des microalgues produites sur des eaux souterraines salées de la baie de Bourgneuf. La baie de Bourgneuf (France) est un important site de production conchylicole. Dans les marais littoraux, la culture intensive et l'affinage d'huîtres nécessitent la production en masse de microalgues. Les eaux souterraines salées, facilement exploitables dans cette région, sont majoritairement utilisées dans la production des microalgues pour l'aquaculture en baie de Bourgneuf. Des études ont été menées sur les cultures de microalgues sur ces eaux souterraines salées et ont mis en évidence une accumulation de plomb $(\mathrm{Pb})$ supérieure à la norme alimentaire en vigueur dans différents échantillons de pâte d'algue d'Haslea ostrearia issus de ces cultures. L'objectif de cette étude est de comparer la croissance, la composition biochimique globale et l'accumulation des métaux ( $\mathrm{Cd}, \mathrm{Cu}, \mathrm{Pb}, \mathrm{Zn})$ pour quatre microalgues, utilisées en aquaculture, cultivées sur des eaux souterraines salées provenant de deux forages différents et sur un milieu enrichi à base d'eau de mer. Les cultures sont réalisées au laboratoire dans des conditions expérimentales contrôlées. Les eaux souterraines salées permettent la production de cultures d'une biomasse et d'une qualité biochimique au moins équivalentes à celles réalisées sur le milieu enrichi à base d'eau de mer. Les teneurs en métaux dans les microalgues ne sont pas différentes pour les algues cultivées sur les différents milieux, à l'exception de Skeletonema costatum qui, cultivée sur une des eaux souterraines, peut présenter des teneurs supérieures à la norme alimentaire en vigueur. Ces observations soulèvent des questions sur la biodisponibilité des métaux dans les eaux souterraines salées et soulignent la spécificité de l'accumulation des métaux dans les microalgues.
\end{abstract}

\section{Introduction}

On the French Atlantic Coast, the Bay of Bourgneuf $\left(46-47^{\circ} \mathrm{N}, 1-2^{\circ} \mathrm{W}\right)$ is an important site of shellfish production with about 10000 tons per year of the Pacific oyster

\footnotetext{
a Corresponding author: sindy.gagneux@univ-nantes.fr
}

Crassostrea gigas (Thunberg) and about 2700 tons per year of the blue and Mediterranean mussels Mytilus edulis (Linné) and M. galloprovincialis (Lamarck) (Barret 2003). Extensive oyster farming takes place on large intertidal flats while oyster intensive rearing and fattening are located in salt ponds in neighbouring marshes. In the latter case, bivalves are fed on outdoor batch cultures of microalgae supplied from salt 
Table 1. Accumulation of cadmium and lead by Haslea ostrearia, results obtained with five samples of algal paste during the experimentations designed by the local authorities (SMIDAP, unpublished study, May 2000).

\begin{tabular}{lrrrrrr} 
& \multicolumn{4}{c}{ Haslea ostrearia (algal paste) } & \multicolumn{2}{c}{ French food } \\
\cline { 2 - 6 } & Sample 1 & Sample 2 & Sample 3 & Sample 4 & Sample 5 & regulation standard \\
\hline $\mathrm{Cd}\left(\mu \mathrm{g} \mathrm{g}^{-1} \mathrm{DW}\right)$ & 0.18 & 0.42 & 0.14 & 0.31 & 0.56 & 0.50 \\
$\mathrm{~Pb}\left(\mu \mathrm{g} \mathrm{g}^{-1} \mathrm{DW}\right)$ & 11.00 & 8.70 & 10.63 & 6.50 & 6.30 & 5.00 \\
\hline
\end{tabular}

groundwaters as culture media (Baud and Bacher 1990; Robert 1990; Baud et al. 1991). The salt groundwaters, discovered in this area around 1980, originating from subterranean saline aquifers, are present all along the bay (Robert 1990; Moreau 1998). Their high nutrient content and accessibility allowed the development of low cost production of microalgae (Baud and Bacher 1990; Bacher and Baud 1992; Sauriau et al. 1997; Barillé et al. 2003). Phaeodactylum tricornutum (Bohlin), Skeletonema costatum (Cleve) and Tetraselmis suecica (Butcher) are cultivated in hatcheries to feed oyster larvae and post-larvae (Coutteau and Sorgeloos 1992; Lavens and Sorgeloos 1996). S. costatum is the main diatom used in intensive rearing and in broodstock feeding of the oyster Crassostrea gigas in the polders of the Bay of Bourgneuf (Baud et Bacher 1990; Muller-Feuga 2000; Barillé et al. 2003). This diatom, well adapted to the quality of the saline groundwater that contains high amounts of ammonia and silica (Baud and Bacher 1990) is an adequate species for bivalve rearing (Baud and Bacher 1990; Muller-Feuga 2000; Barillé et al. 2003). In addition to the oyster fattening, the greening of oyster gills improves the product pre-market value. The diatom Haslea ostrearia (Simonsen) is involved in this phenomenon that gives appreciation to oysters. This diatom thrives naturally in ponds on the western coast of France (Robert 1983; Turpin et al. 1999) but in an unpredictable way depending on the variations of environmental factors. Consequently, in order to control the greening of oysters and to improve the final product quality, local producers developed batch cultures of $H$. ostrearia.

Taking into account that the bioaccumulation of metals in bivalves results mainly from their trophic uptake (e.g. Géret 2000; Wang 2002), it is relevant to evaluate the transfer of metals from water to algae. Several authors have evaluated the bioaccumulation of metals, in seawater media, by P. tricornutum (Zhou and Wangersky 1989; Cid et al. 1995; Kudo et al. 1996; Torres et al. 1998), S. costatum and T. suecica (Nassiri 1995; Nassiri et al. 1996; Perrein-Ettajani et al. 1999). However, very few studies have been conducted on the bioaccumulation of metals by H. ostrearia (Ettajani et al. 1992; Minier et al. 1998). The salt groundwaters used in microalgae cultures in the marshes along the Bay of Bourgneuf contain high concentrations of metals (Moreau 1998). Local authorities carried out metal analyses in algal products and put to the fore the accumulation of non essential metals like $\mathrm{Pb}$ and $\mathrm{Hg}$ in some cultures of $H$. ostrearia, preventing their use in agri-food or cosmetology (SMIDAP, unpublished study, Table 1).

However, to the best of our knowledge, no study has been specifically been conducted on the bioaccumulation of metals in these species grown in these salt groundwaters. As these groundwaters are used to produce microalgal cultures to feed animals or to be transformed for agri-food or cosmetology, it is important to know the final quality of obtained microalgae. In this study, we aimed to assess the physico-chemical characteristics of salt groundwaters from two different drills in marshes near the Bay of Bourgneuf and their respective influence on growth, total carbohydrate and protein concentrations, and metal (cadmium, copper, lead and zinc) accumulation of four microalgae (H. ostrearia, P. tricornutum, S. costatum, T. suecica) was established by comparison with results obtained with the same microalgae grown in coastal seawater based medium.

\section{Material and methods}

\subsection{Sampling}

Salt groundwaters were collected from two wells in the polder area of the Bay of Bourgneuf, named "Ifremer station" and "Bouin". Both salt groundwaters are used to produce microalgae given as food to bivalves. During the pumping, a quick reoxygenation induces the formation of iron oxides to which phosphates associate (Moreau 1998; Partridge 2002). So, the Ifremer salt groundwater cannot be used directly for bivalve rearing due to the risk of gill clogging (Partridge 2002). Hence, prior to its use in bivalve ponds, the Ifremer salt groundwater is oxygenated to transform ammoniacal nitrogen into nitrates and iron oxides are removed (Baud et al. 1991). For this study, both untreated and treated Ifremer groundwater and Bouin groundwater were collected. Seawater was hand-collected on the west coast of Noirmoutier Island $\left(47^{\circ} \mathrm{N}\right.$, $2.2^{\circ} \mathrm{W}$, France). Chemical analysis and experiments were carried out with untreated Ifremer groundwater, treated Ifremer groundwater, Bouin groundwater and coastal seawater.

Waters for algal cultures were stored in a dark room at $4{ }^{\circ} \mathrm{C}$ in $60 \mathrm{~L}$ containers, pre-cleaned with a detergent, an acidic solution and rinsed three times with the collected water. Ten samples for each studied water were collected in pre-cleaned polypropylene (6) or glass (4) bottles $(100 \mathrm{~mL})$. The method used for cleaning the sample containers was modified from the methods described by Laxen and Harrison (1981). Bottles were soaked with nitric acid $(0.5 \mathrm{M})$ and hydrochloric acid (1 M) during 48 hours, and then rinsed three times with Milli $\mathrm{Q}$ water to remove residual acid.

Two of the sample sets were acidified to $\mathrm{pH} 2$ with $1 \mathrm{~mL} \mathrm{~L}^{-1}$ of concentrated hydrochloric acid (Fischer Scientific, trace analysis quality) for total metal determination. For the analysis of the ammonium concentration, reagents were added in situ to the four samples collected in glass bottles. The remaining four samples were brought back to the laboratory and kept frozen until nutrient analyses. 
Table 2. Detection limits of the analysed metals. Differential pulse anodic stripping voltammetry (DP-ASV) on acidified and UV-treated samples; atomic absorption spectrometry (AAS).

\begin{tabular}{lcccc}
\hline Detection limits & $\mathrm{Cd}$ & $\mathrm{Cu}$ & $\mathrm{Pb}$ & $\mathrm{Zn}$ \\
\hline DP-ASV $\left(\mu \mathrm{g} \mathrm{L}^{-1}\right)$ & 0.08 & 0.22 & 0.16 & 0.65 \\
$\mathrm{AAS}\left(\mu \mathrm{g} \mathrm{g}^{-1}\right)$ & 0.01 & 0.41 & 0.29 & 0.69 \\
\hline
\end{tabular}

\subsection{Water analysis}

The following nutrient concentrations in seawater and salt groundwaters were determined with an autoanalyser SKALAR: nitrogen $\left(\mathrm{NO}_{3}^{-}\right.$and $\left.\mathrm{NO}_{2}^{-}\right)$, inorganic phosphorus and inorganic silicon (Strickland and Parsons 1972). After the collection of the samples, the ammoniacal nitrogen was analysed according to the Koroleff (1969) method modified by Grasshof and Johannsen (1972). The salinity was measured both by refractometry in situ, and conductimetry in the laboratory. The alkalinity induced by carbonates was measured according to the method described by Culberson and Hawley (1970) and Strickland and Parsons (1972) based on the reactions of Hansson (1973a,b) and Mehrbach et al. (1973). This method was adapted to salt groundwaters by Moreau (1998).

Total $\mathrm{Cd}, \mathrm{Cu}, \mathrm{Pb}$ and $\mathrm{Zn}$ were quantified by differential pulse anodic stripping voltammetry (DP-ASV) on acidified and UV-treated samples according to the method described by Nürnberg (1983). Analyses were performed with a polarograph (EG \& G M394) coupled to a voltammetric cell (EG $\&$ G model 303A) fitted with a hanging mercury drop electrode, a platinum counter electrode and an $\mathrm{Ag} / \mathrm{AgCl}$ reference electrode. Samples $(10 \mathrm{~mL})$ of water were introduced in the temperature-controlled cell at $20{ }^{\circ} \mathrm{C}$, degassed for $240 \mathrm{~s}$ with $\mathrm{N}_{2}$ to remove the dissolved oxygen, which can interact with the mercury electrode. For the pre-electrolysis, the deposition potential was switched to $-1.2 \mathrm{~V}$ for $60 \mathrm{~s}$; the bulk solution was stirred from the bubbling step to the end of the pre-electrolysis to ensure the proportionality between the quantity of metals reacting with the mercury drop and the bulk concentration. After the deposition step, an equilibration step of $30 \mathrm{~s}$, without stirring, allowed a homogeneous distribution of metals on the mercury drop. The stripping step consisted in a potential scanning from $-1.2 \mathrm{~V}$ to $-0.1 \mathrm{~V}$. The currents created by the reduction of the metals from the amalgams were recorded forming peaks at specific potentials for $\mathrm{Zn}(-1.1 \mathrm{~V}), \mathrm{Cd}(-0.7)$, $\mathrm{Pb}(-0.5 \mathrm{~V})$ and $\mathrm{Cu}(-0.2 \mathrm{~V})$. Metal concentrations were estimated with reference to three additions of a standard mixedmetal solution in the bulk analysed according to the same procedure.

The detection limits and the reproducibility of the method were calculated from 10 repetitive analyses of an acidified UV-treated seawater sample, on which the sensitivity was calculated from standard additions. Table 2 shows the obtained values for detection limits.

\subsection{Cultures of microalgae}

The cultures were performed in erlenmeyers flasks $250 \mathrm{~mL}$, acid-cleaned and sterilized before filling with seawater or salt groundwater. In the experimental conditions used, the strains of selected microalgae could not develop efficiently on coastal seawater. Thus, seawater was enriched with some nutrients $(\mathrm{N}, \mathrm{P}, \mathrm{Si})$ to obtain similar concentrations as in salt groundwaters and with the $\mathrm{f} / 2$ trace metal solution according to Guillard (1982). The enriched seawater medium was sterilized by autoclave ( 1 bar, $120{ }^{\circ} \mathrm{C}$ for $20 \mathrm{~min}$ ) to prevent the development of microalgae or bacteria naturally present in seawater samples. In the opposite, we did not observe living organisms in these salt groundwaters and Baud and Bacher (1990) did not noticed anymore the presence of bacteria or microalgae.

Salt groundwaters were not sterilized by autoclave to avoid a loss of elements by precipitation. As the presence of sedimented particulate matter (iron oxides) has been observed, the sterilization by filtration was excluded to prevent a loss of elements (mainly iron and phosphates) by retention on the filter membrane. The formation of iron oxides did not modify the total metal concentration but only the speciation of metals in salt groundwaters.

All the algal strains were provided by the Nantes Culture Collection (WDCM 856, ISOMer, Université de Nantes, France). Phaeodactylum tricornutum (NCC 45, size: $30 \mu \mathrm{m}$ ) and Skeletonema costatum (NCC 52, size: $15 \mu \mathrm{m}$ ) were isolated from coastal water of the Bay of Bourgneuf (France). Tetraselmis suecica (NCC 62, size: $8 \mu \mathrm{m}$ ) was isolated from a sample of coastal seawater of Le Croisic (Loire-Atlantique, France). Haslea ostrearia (NCC 143, size: $70 \mu \mathrm{m}$ ) came from a greening oyster pond in the area of Bourgneuf marshes.

All the culture experiments were performed at $17^{\circ} \mathrm{C}$ under $80 \mu \mathrm{mol}$ photon $\mathrm{m}^{-2} \mathrm{~s}^{-1}$ of irradiance and a $14: 10 \mathrm{~h}$ light:dark cycle. Strains were introduced at 5000 cell $\mathrm{mL}^{-1}$ in the flasks filled with $150 \mathrm{~mL}$ of enriched seawater or salt groundwater. All experiments were run in four replicates. The cell density (number of cells per $\mathrm{mL}$ ) was determined daily from the beginning of the exponential phase to the stationary phase using Nageotte (for H. ostrearia) or Neubauer (for the other microalgae) hematocymeters.

In an effort to facilitate the presentation of the results, the different media used to grow our microalgae will be represented by the following acronyms: Ifremer salt Groundwater IG (Untreated: UIG; Treated: TIG), Bouin salt Groundwater BG and Enriched coastal SeaWater ESW.

\subsection{Biochemical and chemical analyses}

At the stationary growth phase, cultures were filtered, using glass microfibre Whatman GF-F filters, in order to determine the cellular carbohydrate, carotenoid, chlorophyll $a$ and protein concentrations by the spectrophotometric methods of Dubois et al. (1956), Richards and Thompson (1952), Lorenzen (1967) and Lowry et al. (1951), respectively. Carbohydrate, photosynthetic pigment and protein concentrations were used to assess the quality of the algal cultures. To determine the amount of metals accumulated by the algal cells, cultures were filtered using pre-weighted cellulose nitrate membrane Sartorius filters $(0.8 \mu \mathrm{m})$. Filters were dried at $60{ }^{\circ} \mathrm{C}$, weighted to determine algal dry weight and digested with 1 $\mathrm{mL}$ concentrated nitric acid (Fisher Scientific, trace analysis). $\mathrm{Cu}$ and $\mathrm{Zn}$ were determined by flame atomic absorption spectrometry FAAS (Varian Spectr AA 250 Plus) while Cd and 
Table 3. Physico-chemical characteristics of salt groundwaters (Untreated Ifremer Groundwater UIG, Treated Ifremer Groundwater TIG and Bouin Groundwater BG), coastal seawater (SW) and enriched coastal seawater (ESW): pH, salinity, alkalinity, nutrient and trace metal concentrations. Mean \pm confidence interval.

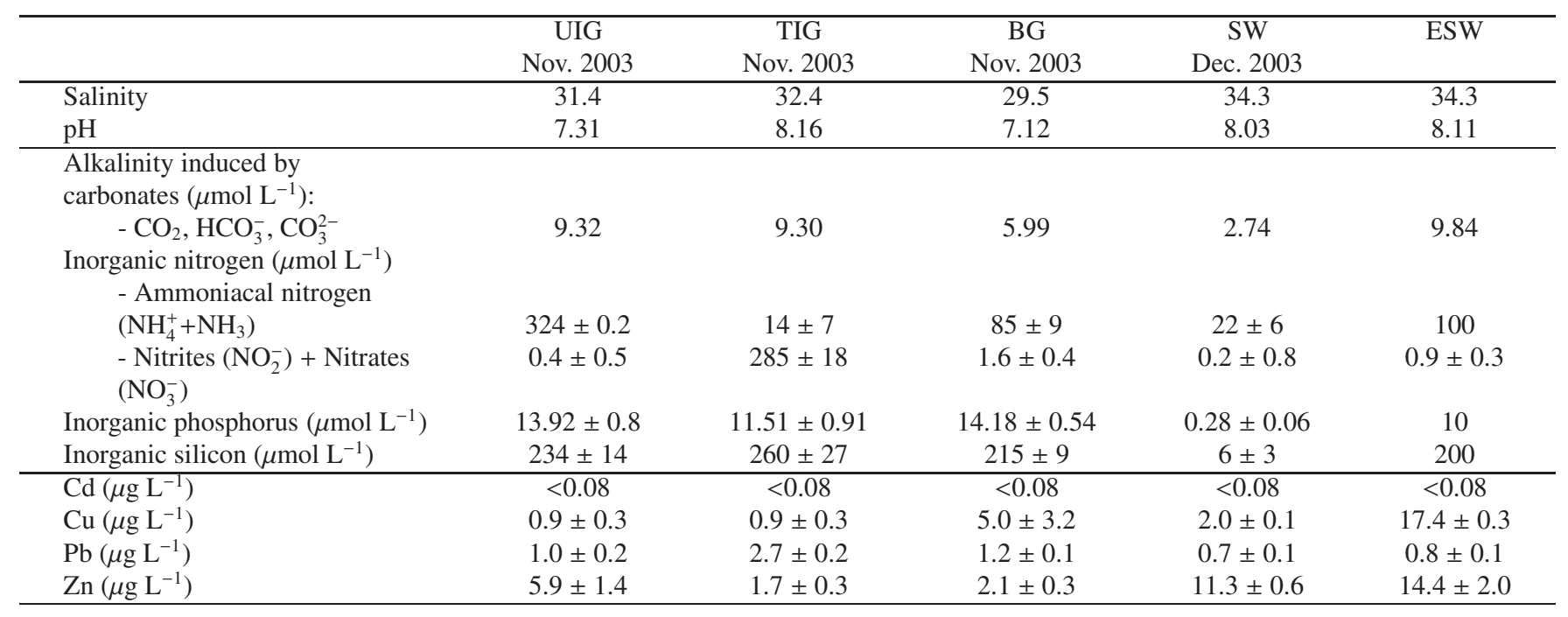

$\mathrm{Pb}$ were determined by electrothermal atomic absorption spectrometry EAAS (Hitachi Z5000 Polarized Zeeman AAS) in the acidic solutions. Eight blanks were realised in the same analytical conditions to determine detection limits. Table 2 shows the obtained values for the detection limits. Reference material (IAEA 140, sea plant homogenate) was treated and analysed in the same way as the samples; the results of the standard reference material was in good agreement with certified values.

\subsection{Statistical analysis}

Data on growth, carbohydrate and protein contents and metal bioaccumulation obtained for microalgae grown in groundwaters and enriched seawater were compared using one-way analysis of variance (ANOVA). After checking the normality and the homogeneity of variances, a posteriori tests (Tukey tests) were run with ANOVA data. Some series that did not verify normality or homogeneity of variances were tested using ANOVA on ranks and a posteriori Dunn's test.

\section{Results}

\subsection{Physico-chemical parameters of waters}

Data for $\mathrm{pH}$, alkalinity, nutrients and trace metals are presented in the Table 3. The $\mathrm{pH}$ of the salt groundwaters UIG and $\mathrm{BG}$ were more acid ( $\mathrm{pH}$ close to 7 ) than the $\mathrm{pH}$ of $\mathrm{SW}$ and TIG ( $\mathrm{pH}$ close to 8). TIG presented a higher $\mathrm{pH}$ than that observed for UIG owing to the transformation of the amoniacal nitrogen in nitrates.

Carbonates and nitrogen were higher in IG than in BG $(p<0.001)$. Both groundwaters (IG and BG) were richer $(p<0.001)$ in major nutrients $(\mathrm{N}, \mathrm{P}, \mathrm{Si})$ than seawater. A decrease of the concentration of the inorganic phosphorus was observed between UIG and TIG. The concentration of $\mathrm{Cd}$ was lower, for all the collected samples, than the quantification limit of the method calculated for our analytical protocol. The $\mathrm{Cu}$ concentration of the groundwater $\mathrm{BG}$ was higher $(p<0.05)$ than the concentration of the groundwater IG, while, for $\mathrm{Zn}$, the opposite was observed. The level of $\mathrm{Cu}$ in seawater was higher than in IG but lower than in BG. Nevertheless, the input of copper from the $\mathrm{f} / 2$ enrichment solution should be taken in consideration towards the potential accumulation of $\mathrm{Cu}$ in the microalgae.

The highest concentration in $\mathrm{Zn}$ was found in seawater. TIG , unexpectively, contained less $\mathrm{Zn}$ than UIG, respectively 1.7 and $5.9 \mu \mathrm{g} \mathrm{L}^{-1}$.

TIG had a higher concentration in $\mathrm{Pb}$ that could come from the treatment system itself.

\subsection{Microalgal growth}

The growth curves of the four microalgae cultivated in salt groundwaters and enriched seawater are presented in Figure 1. All four algae grown in groundwaters reached densities (cell $\mathrm{mL}^{-1}$ ) as high as that observed when grown in ESW. The densities of T. suecica and H. ostrearia were higher $(p<0.001)$ when cultures were performed in TIG. T. suecica had a better development in UIG than in BG or in ESW. $H$. ostrearia could not develop in UIG. The results presented in Figure 1 are those obtained when $H$. ostrearia was grown in the UIG half-diluted with coastal seawater. The densities of $H$. ostrearia were statistically the same in the cultures realised in dilute UIG, BG or ESW. Densities of P. tricornutum grown in $\mathrm{BG}$ and ESW were similar and its development was greater in BG than in IG $(p<0.001)$. S. costatum reached a higher cell density when cultures grew in IG. 


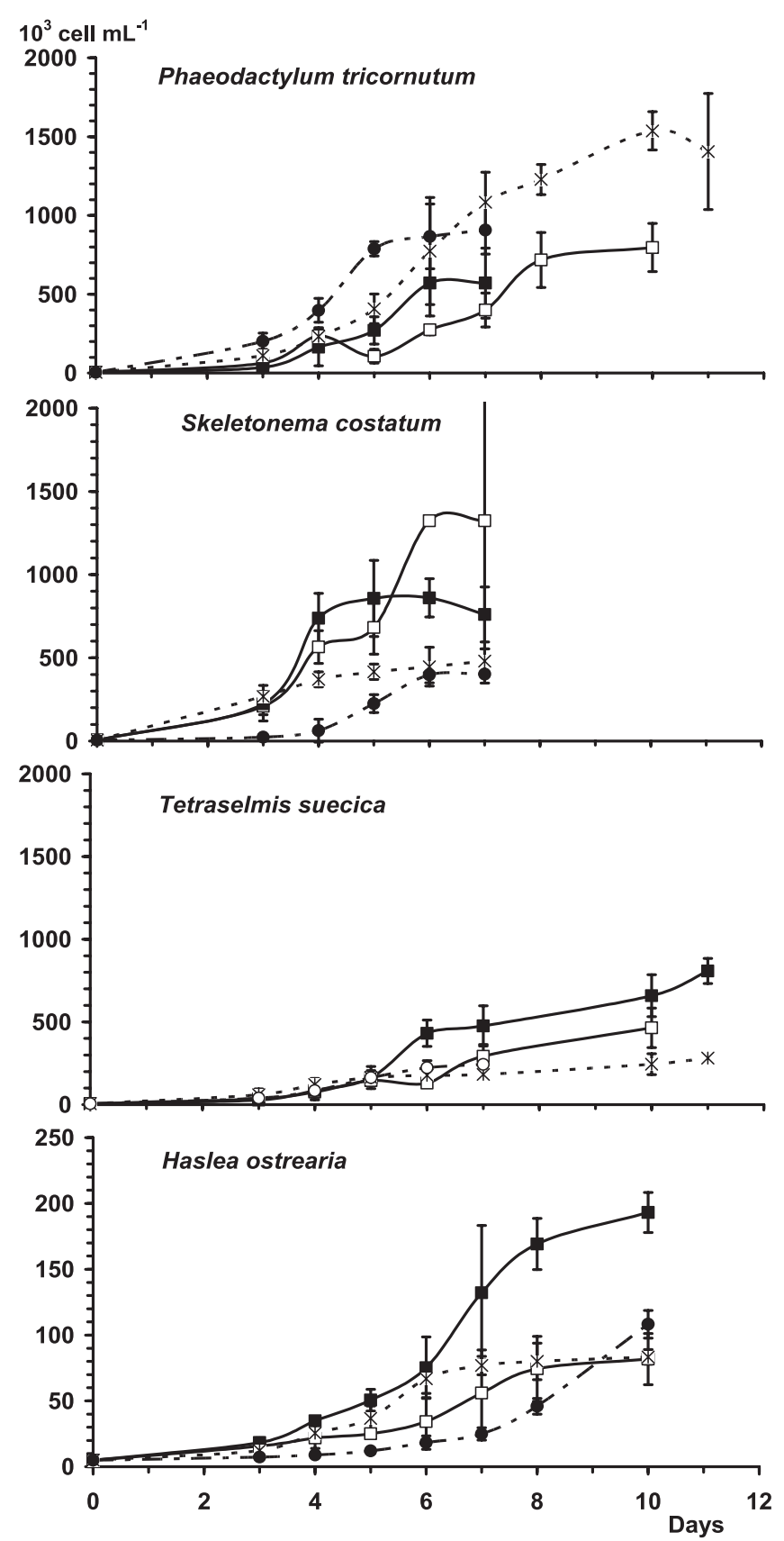

Fig. 1. Growth $\left(10^{3}\right.$ cell $\left.\mathrm{mL}^{-1}\right)$ of microalgae (Phaeodactylum tricornutum, Skeletonema costatum, Tetraselmis suecica, Haslea ostrearia) in $(-\square-)$ Untreated Ifremer Groundwater (UIG), (- - ) Treated Ifremer Groundwater (TIG), $(*)$ Bouin Groundwater $(\mathrm{BG})$ and $(\bullet-)$ Enriched SeaWater (ESW). Mean \pm confidence interval.

\subsection{Biochemical composition of microalgal cells}

The partial biochemical composition of microalgal cells is presented in Figure 2. Pigment (carotenoids and chlorophyll $a+$ pheopigments), protein and carbohydrate contents are expressed per cell. In general, pigment, carbohydrate and protein concentrations, in cultures grown in one or the other groundwater, were at least equal to or higher than those grown in ESW.

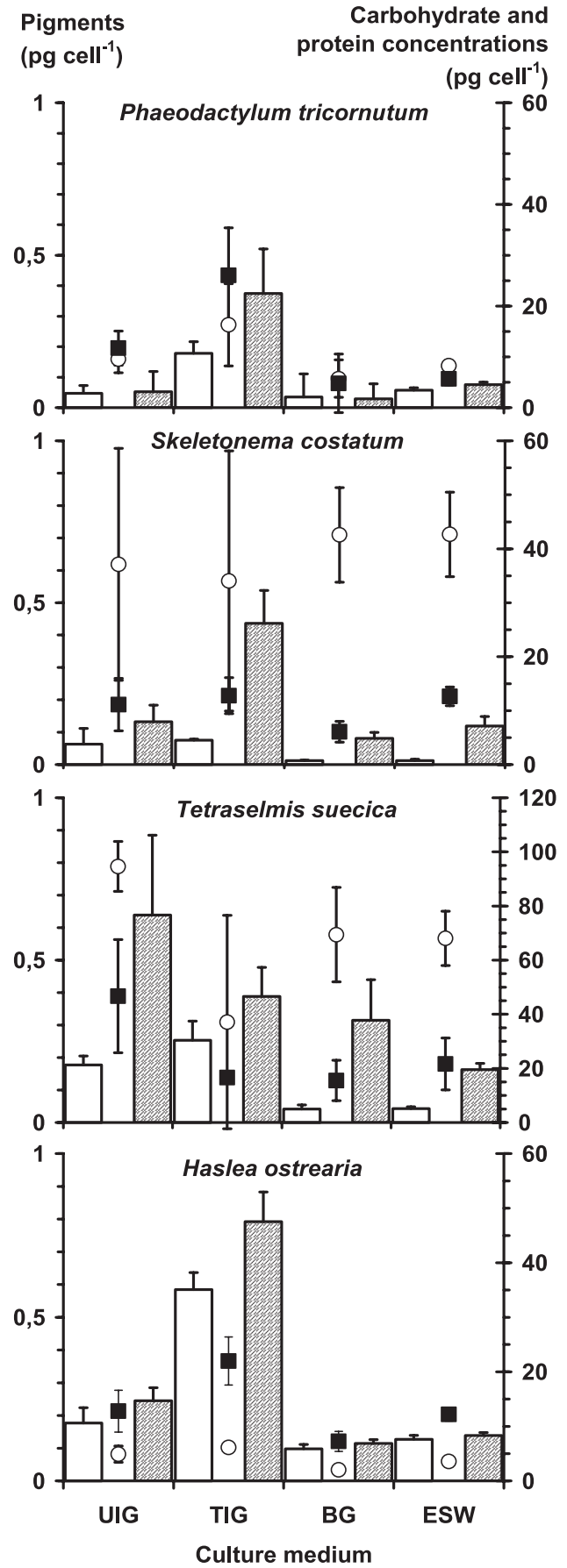

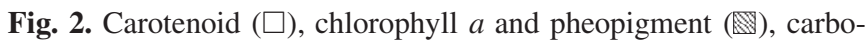
hydrate $(\bigcirc)$ and protein $(\square)$ contents of cultures $\left(\mathrm{pg} \mathrm{cell}^{-1}\right.$ ) grown in Untreated Ifremer Groundwater (UIG), Treated Ifremer Groundwater (TIG), Bouin Groundwater (BG) and Enriched SeaWater (ESW). Mean \pm confidence interval.

Cultures of $P$. tricornutum in Ifremer groundwater (IG) showed higher carbohydrate and protein contents than cultures grown in BG or in ESW. The carotenoid content was higher $(p<0.001)$ in cultures grown in TIG compare to the other three media.

Cultures of $S$. costatum, grown in TIG, contained significantly $(p<0.001)$ higher levels of pigments (carotenoids and 
chlorohyll $a+$ pheopigments) compare to the other media, for which pigment cell contents were statistically similar. Protein content in cultures grown in BG was lower $(p<0.05)$ than in the other cultures, whereas carbohydrate concentration was higher in BG or ESW cultures than in IG cultures.

For T. suecica, pigment, carbohydrate and protein contents were twice as high $(p<0.001)$ in UIG cultures as those in the other cultures (TIG, BG or ESW). TIG cultures had lower $(p<0.05)$ carbohydrate contents than the other cultures.

Similarly, pigment content was larger in cultures of $H$. ostrearia grown in Ifremer groundwaters. Carbohydrate concentration was higher $(p<0.05)$ in cultures of $H$. ostrearia grown in UIG than in the other three media. The protein concentration for these cultures was also higher when grown in UIG, but only cultures grown in ESW had significant lower protein concentration.

\subsection{Microalgal metal uptake}

The accumulation of $\mathrm{Cd}$ and $\mathrm{Cu}$ by microalgae is presented in Figure 3.

No difference of $\mathrm{Cd}$ accumulation was observed whatever the medium used to grow $P$. tricornutum, $T$. suecica or $H$. ostrearia. The Cd concentrations in T. suecica and H. ostrearia were under the French food regulation standard value $\left(0.5 \mu \mathrm{g} \mathrm{g}^{-1}\right)$.

The diatom $S$. costatum grown in TIG accumulated more $\mathrm{Cd}$ than when it was grown in ESW ( $p=0.036)$. $S$. costatum showed Cd concentrations that tended to be higher than the French food regulation standard value when it was grown in TIG or BG, but this tendency was not confirmed statistically.

The accumulation of $\mathrm{Cu}$ varied according to the species and the medium. S. costatum and $H$. ostrearia accumulated a higher amount of $\mathrm{Cu}$ when grown in ESW compared to cultures grown in Ifremer groundwaters. The $\mathrm{Cu}$ content in $S$. costatum grown in ESW was also higher than in cultures grown in BG. Among salt groundwaters, no difference was observed for $\mathrm{Cu}$ in both microalgae. For $P$. tricornutum, no significant difference in $\mathrm{Cu}$ bioaccumulation occured among the cultures. T. suecica showed a lower accumulation of $\mathrm{Cu}$ grown in TIG than cultures grown in the other three media.

The quantification of $\mathrm{Pb}$ in the microalgae gave results lower than the detection limit of the analytical method, EAAS. The concentration limit of $\mathrm{Pb}$ expressed per gram of algal dry weight was estimated for each alga. A level of $\mathrm{Pb}$ higher than the authorised value $\left(5 \mu \mathrm{g} \mathrm{g}^{-1}\right)$ would have been quantified with our analytical protocol.

The values measured for $\mathrm{Zn}$ for the different replicates were too erratic to yield any information about $\mathrm{Zn}$ accumulation by microalgae in our experimental conditions.

\section{Discussion}

In the present study, both salt groundwaters provided cultures with a cell density, carbohydrate and protein cell contents and pigment cell contents similar to that grown in enriched coastal seawater, which suggested similar quality of algal cultures. The advantage using salt groundwater is an overall lower
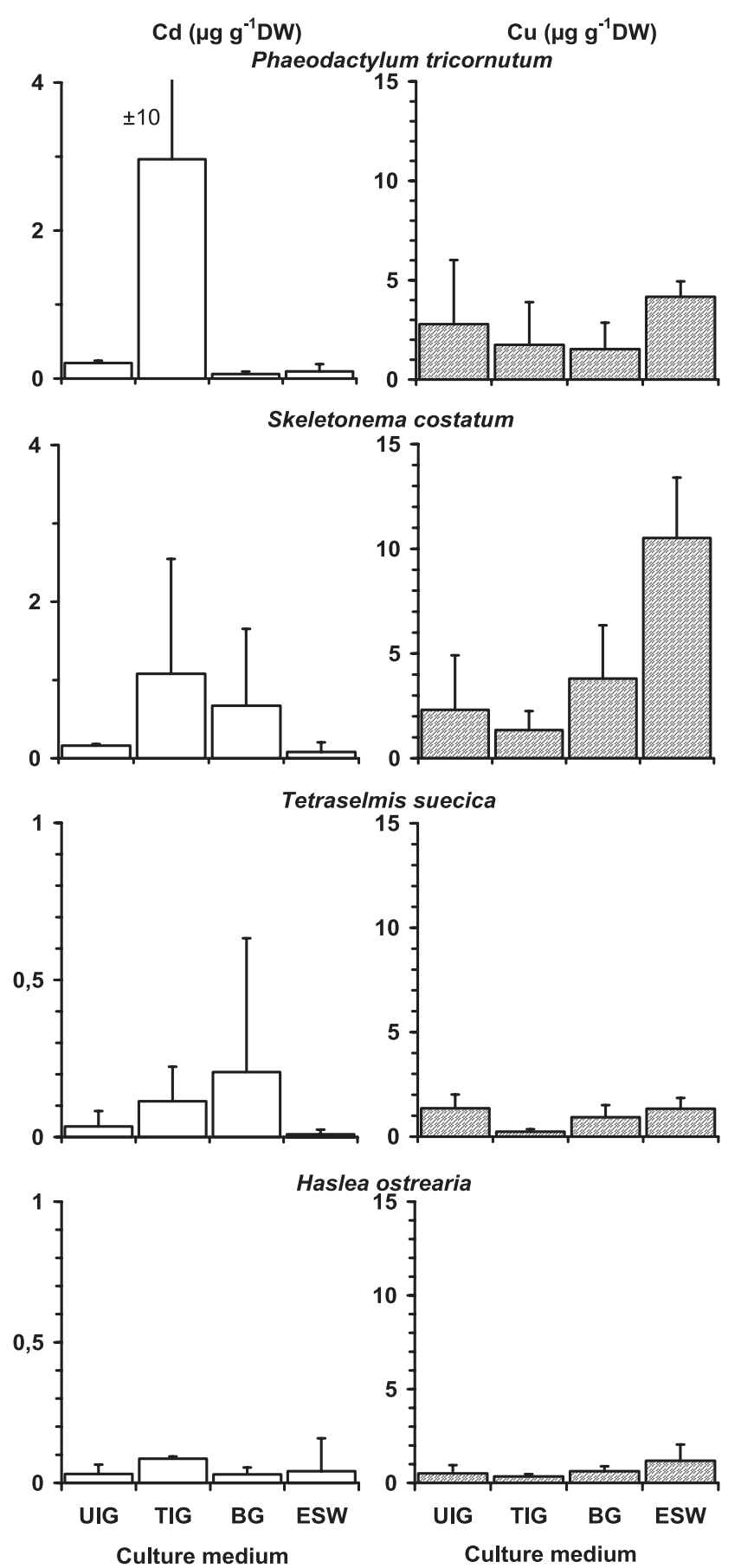

Fig. 3. Figure $3 \mathrm{Cd}(\square)$ and $\mathrm{Cu}(\mathbb{W})$ contents of cultures $\left(\mu \mathrm{g} \mathrm{g}^{-1}\right.$ Dry Weight) grown in Untreated Ifremer Groundwater (UIG), Treated Ifremer Groundwater (TIG), Bouin Groundwater (BG) and Enriched SeaWater $(E S W)$. Mean \pm confidence interval.

cost since nothing has to be added to the medium, contrarily to seawater that is often enriched with $\mathrm{f} / 2$ solutions (Guillard 1982) in mass algal cultures (Lavens et Sorgeloos 1996). However, both groundwaters do not sustain with the same efficiency each species of studied microalgae. Although the drills where the groundwater was collected from are only distant by a few kilometres, the observed differences in their composition and 
Table 4. Concentration in total ammoniacal nitrogen $\mathrm{NH}_{3,4}$ and in ammonia $\mathrm{NH}_{3}$ (caculated with Johnasson and Wedborg's equations, 1980 ) in the groundwaters and the enriched seawater.

\begin{tabular}{lcc}
\hline & $\begin{array}{c}\mathrm{NH}_{3,4} \\
\left(\mu \mathrm{mol} \mathrm{L}^{-1}\right)\end{array}$ & $\begin{array}{c}\mathrm{NH}_{3} \\
\left(\mu \mathrm{mol} \mathrm{L}^{-1}\right)\end{array}$ \\
\hline Untreated Ifremer Groundwater (UIG) & 324 & 1.98 \\
Dilute UIG & 173 & 1.66 \\
Treated Ifremer Groundwater (TIG) & 14 & 0.58 \\
Bouin Groundwater (BG) & 85 & 0.34 \\
Enriched SeaWater (ESW) & 100 & 3.70 \\
\hline
\end{tabular}

aptitude to be used as growing medium for microalgae were significant. In a previous study, Moreau (1998) noticed this disparity in salt groundwater quality among several drills installed in the marshes along the Bay of Bourgneuf, and put forward gradients of nutrients and salinity following the geographic location. From the coast inland, total ammoniacal nitrogen and $\mathrm{Mn}$ concentrations increase while total Fe concentration and salinity decrease. According to the productivity of the three diatoms ( $P$. tricornutum, S. costatum and $H$. ostrearia) grown in several groundwaters, this author showed different levels of tolerance/need concerning the total ammoniacal nitrogen $\left(\mathrm{NH}_{3}+\mathrm{NH}_{4}^{+}\right)$concentration. For these species, the optimal concentration (respectively: 2000, 250-300 and 110-130 $\mu \mathrm{mol} \mathrm{L}^{-1}$ ) and the toxic concentration (respectively: 8000, 500 and $150-160 \mu \mathrm{mol} \mathrm{L}{ }^{-1}$ ) were determined. In the present study, results concerning $S$. costatum and $H$. ostrearia are congruent with the previous observations. H. ostrearia did not grow in the groundwater UIG that contains $\mathrm{NH}_{3,4}$ concentration about $300 \mu \mathrm{mol} \mathrm{L}{ }^{-1}$. The dilution of UIG with coastal seawater decreased the $\mathrm{NH}_{3,4}$ concentration lower than $180 \mu \mathrm{mol} \mathrm{L}^{-1}$ and allowed the development of the diatom in this medium. Actually, the ammonia concentration $\left(\mathrm{NH}_{3}\right)$, that is the toxic form of nitrogen for the microalga, is to be considered rather than the total ammoniacal nitrogen $\left(\mathrm{NH}_{3}+\mathrm{NH}_{4}^{+}\right)$ when discussing nitrogen toxicity. The proportion of $\mathrm{NH}_{3} \mathrm{re}-$ lated to the total ammoniacal nitrogen depends on salinity, $\mathrm{pH}$ and temperature (Abeliovich and Azov 1976). In Table 4, we can observe that $\mathrm{NH}_{3}$ concentrations in all media were lower than the toxic $\mathrm{NH}_{3}$ concentration level described by Moreau (1998).

Although UIG appeared to be unsuitable to the development of $H$. ostrearia, this groundwater was the most convenient medium for the development of $S$. costatum. This is in agreement with the optimal ammoniacal nitrogen concentration found by Moreau (1998) for this diatom. Baud and Bacher (1990) have already shown that this diatom was well adapted to this kind of medium. On the contrary, regarding the influence of ammoniacal nitrogen concentration in a culture medium, our results for P. tricornutum were not consistent with the study of Moreau (1998). UIG would be expected to be the most suitable medium owing to its high concentration in ammoniacal nitrogen. However the highest cell density was observed when our P. tricornutum strain was grown in BG.

Higher carbohydrate, pigment and protein levels in cells of $P$. tricornutum grown in TIG were in contradiction with the low cell densities achieved in these cultures. Whereas the cell density in TIG culture was twice lower than that in BG cultures, slightly lower than that in ESW culture and equal to that in UIG culture, the chlorophyll $a$ concentration of TIG culture, expressed per $\mathrm{mL}$ of culture, was five times higher than that of UIG or ESW cultures and eleven times higher than that of BG cultures, with statistical significance at $\alpha<0.001$. The carbohydrate and protein concentration increase observed when $P$. tricornutum was cultured in TIG were not as important as the chlorophyll $a$ concentration increase. The increase of chorophyll $a$ in $P$. tricornutum cells grown in TIG compared to the other media could be associated to a higher need in energy in order to reduce nitrates (the nitrogen form found in TIG) into ammonium (the nitrogen form used in the cell metabolism). A similar relation between nitrate reduction and photosynthesis was established for cyanobacteria (Serrano et al. 1981; Flores et al. 1983, 2005). In this study, such a relation has not been put forward for the other three microalgae.

Regarding the metal enrichment in groundwaters, cultures did not present systematic accumulation of metals $(\mathrm{Cd}, \mathrm{Cu}$ and $\mathrm{Pb}$ ) suggesting a low bioavailability of these metals for the selected microalgae, except for Skeletonema costatum that presented high cadmium concentrations. These observations are not congruent with the earlier studies in which high levels of $\mathrm{Pb}$ have been found in H. ostrearia cultures (SMIDAP, pers. comm.). These studies had been performed using relatively different experimental conditions. Actually, previous experiments were realised in outdoor batch cultures in $600 \mathrm{~L}$ tanks whereas cultures in the present study were performed in small volume close flasks with $150 \mathrm{~mL}$ of medium in controlled conditions (temperature, irradiance). Firstly, outdoor batch cultures are exposed to atmospheric $\mathrm{Pb}$ which is the major source of this metal (Nriagu and Pacyna 1988). Moreover, using smaller volumes of culture (Erlenmeyer versus tank) implies a higher surface/volume ratio promoting metal adsorption on the flask, and a shorter culture period reducing the contact period between algae and metals. That can explain the difference of metal accumulation between the previous and the present studies. Furthermore, metals, adsorbed onto the precipitates formed during the oxygenation of the water, could be released with a slow kinetic following the consumption of dissolved metal forms by algae in the medium. In batch cultures performed in the Bay of Bourgneuf (Taraud, pers. comm.), they use semi-continuous culture techniques which consists in the renewing of $70 \%$ of the total volume with salt groundwater while the $30 \%$ of the remained culture is used as algal inoculum (Lavens and Sorgeloos 1996). Then, accumulation of inorganic matter could occur at the bottom of the tank and could constitute a potential reservoir of metals. Another difference between the various studies was the analysed algal product. In the previous studies, cultures were centrifuged to obtain algal pastes that were used for metal analyses. In the present study, cultures were filtered in order to retain cells, which clearly reduced metal contamination due to experimental techniques.

Among the four tested algal strains, P. tricornutum and $S$. costatum present higher concentrations of $\mathrm{Cd}$ and $\mathrm{Cu}$ than the other microalgae. Yet, in earlier studies, Cd accumulation in $T$. suecica has been shown higher than in S. costatum (PerreinEttajani et al. 1999; Ettajani et al. 2001) and in P. tricornutum (Ng et al. 2005). The equilibrium of metal forms found in salt groundwaters would be different from seawater owing to the 
$\mathrm{pH}$ and nutrients contents and would affect specific metal uptake rates of the different strains. Regarding $H$. ostrearia, this diatom is at least five fold longer than the other microalgae and thus, the cells present a smaller surface/volume ratio that can partly explain a lesser metal uptake. One of the microalgae tended to accumulate $\mathrm{Cd}$ reaching levels above the safety guidance limits. That was however not established statically. This statement needs to be confirmed by further experimentations. Contrarily to the previous observations, the H. ostrearia strain used in this studied did not present higher accumulation of metals than the other microalgae.

\section{Conclusion}

The results obtained in the present study are congruent with previous studies regarding the interest of using salt groundwaters to grow microalgal cultures for bivalve rearing and fattening. Salt groundwaters provide cultures with a high nutritional value for a low cost. The previous observations of metal accumulation in $H$. ostrearia were not verified in this experiment; this diatom presents lower metal levels than the other ones (P. tricornutum and $S$. costatum). The experimental conditions previously used for the studies realised at the request of the local authorities presented several differences compared to those adopted in our study explaining the lower accumulation observed in our cultures. It would be interesting to realise long term experiments in different culture volumes to determine the effects on the metal/microalgae interaction of the culture time and of the ratio between the surface of the flask/tank walls and the volume of culture. The study of metal repartition in groundwaters by determining the metal speciation and the complexation capacity of such culture media would allow a better understanding of the metal bioavailability. Furthermore, it seems important to measure the $\mathrm{pH}$ and the algal exudate production all along the culture in order to assess the impact of the algal developement itself on the metal accumulation. Indeed, Sunda et al. (2005) reported that, when the cell concentration in a batch culture becomes sufficiently high, the complexation of metals is higher owing to an increase in the $\mathrm{pH}$ of the medium and the release of metabolites by the algae.

Acknowledgements. We are indebted to the SMIDAP "Syndicat Mixte pour le Développement de l'Aquaculture et de la Pêche des Pays de Loire" for the financial support of the present study and the Region Pays de la Loire for a fellowship (S. G.-M.). Thanks are due to F. Taraud and to the staff of the Ifremer station of Bouin for providing salt groundwater. We also wish to thank P. Gaudin and P. Rosa for their technical assistance and J. Kojadinovic for revising the English text.

\section{References}

Abeliovich A., Azov Y., 1976, Toxicity of ammonia to algae in sewage oxidation ponds. Appl. Environ. Microbiol. 31, 801-806.

Bacher C., Baud J.-P., 1992, Intensive rearing of juvenile oysters Crassostrea gigas in an upwelling system: optimization of biological production. Aquat. Living Resour. 5, 89-98.
Barillé L., Haure J., Pales-Espinosa E., Morançais M., 2003, Finding new diatoms for intensive rearing of the Pacific oyster (Crassostrea gigas): energy budget as a selective tool. Aquaculture 217, 501-514.

Barret J., 2003, La conchyliculture mondiale et française, website Ifremer, available from http://www.ifremer.fr/ aquaculture/conchyliculture/index.htm, updated Sept. 24, 2003, accessed May 1, 2006.

Baud J.-P., Bacher C., 1990, Use of saline groundwater for intensive rearing of Ruditapes philippinarum juveniles in a nursery system. Aquaculture. 88, 157-178.

Baud J.-P., Robert J.-M., Lemoine O., 1991, Potential uses of subterranean salt water for aquaculture on the coast of "Pays de la Loire" (France). EAS Spec. Publ. 14, 23-24.

Cid A., Herrero C., Torres E., Abalde J., 1995, Copper toxicity on the marine microalga Phaeodactylum tricornutum: effects on photosynthesis and related parameters. Aquat. Toxicol. 31, 165-174.

Coutteau P., Sorgeloos P., 1992, The use of algal substitutes and the requirement for live lagae in the hatchery and nursery rearing of bivalves molluscs: an international survey. J. Shellfish Res. 11, 467-476.

Culberson C.D., Hawley J.E., 1970, Seawater alkalinity determination by the $\mathrm{pH}$ method. J. Mar. Res. 28, 15-21.

Dubois F., Gilles K.A., Hamilton J.K., Rebers P.A., Smith F., 1956, Colorimetric method for determination of sugar and related substances. Anal. Chem. 28, 350-356.

Ettajani H., Amiard-Triquet C., Amiard J.-C., 1992, Étude expérimentale du transfert de deux éléments traces $(\mathrm{Ag}, \mathrm{Cu})$ dans une chaîne trophique marine: eau - particules (sédiment naturel, microalgue) - mollusques filtreurs (Crassostrea gigas Thunberg). Water Air Soil Pollut. 65, 215-236.

Ettajani H., Berthet B., Amiard J.C., Chevolot L., 2001, Determination of cadmium partitioning in microalgae and oysters contribution to the assessment of trophic transfer. Arch. Environ. Contam. Toxicol. 40, 209-221.

Flores E., Frías J. E., Rubio L. M., Herrerro A., 2005, Photosynthetic nitrate assimilation in cyanobacteria. Photosynth. Res. 83, 117133.

Flores E., Guerrero M. G., Losada M., 1983, Photosynthetic nature of nitrate uptake and reduction in the cyanobacterium Anacystis nidulans. Biochim. Biophys. Acta 722, 408-416.

Géret F., 2000, Synthèse de métallothionéines chez deux bivalves (l'huître et la moule) en réponse à une contamination métallique par voie directe et par voie trophique, Thèse de doctorat, Université de Nantes.

Grasshof K., Johannsen H., 1972, A new sensitive and direct method for the automatic determination of ammonia in seawater. J. Cons. - Cons. Int. Expl. Mer. 34, 516-521.

Guillard R.R.L., 1982, Culture of phytoplankton for feeding marine invertebrates. In: Smith, W.L., Chanley, M.H. (Eds.), Culture of marine invertebrate animals. Plenum Press, New-York, pp 108139.

Hansson I., 1973a, The determination of dissociation constant of carbonic acid in synthetic sea water in the salinity range of 20-40 and temperature of 5-30 ${ }^{\circ} \mathrm{C}$. Acta Chem. Scand. 27, 931-944.

Hansson I., 1973b, A new set of acidity constants for carbonic acid and boric acid in sea water. Deep-Sea Res. 20, 461-478.

Johansson O., Wedborg M., 1980, The ammonia-ammonium equilibrium in sea water at temperatures between 5 and $25^{\circ} \mathrm{C}$. J. Solution Chem. 9, 37-44.

Koroleff F., 1969, Direct determination of ammonia in natural waters as indophenol blue. ICES, C. M. 1969/C 9, 19-22. 
Kudo I., Kokubun H., Matsunaga K., 1996, Chemical fractionation of phosphorus and cadmium in the marine diatom Phaeodactylum tricornutum. Mar. Chem. 52, 221-231.

Lavens P., Sorgeloos P., 1996, Manual on the production and use of live food for aquaculture. FAO Fish. Techn. Pap. 361, FAO, Rome.

Laxen D.P.H., Harrison R.M., 1981, Cleaning methods for polythene containers prior to the determination of trace metals in freshwater samples. Anal. Chem. 53, 345-350.

Lorenzen C.J., 1967, Determination of chlorophyll and pheopigments: spectrophotometric equations. Limnol. Oceanogr. 12, 343-346.

Lowry G.H., Rosebrough N.J., Faar A.L., Randall R.J., 1951, Protein measurement with the Folin phenol reagent. J. Biol. Chem. 193, 265-275.

Mehrbach C., Culberson C.H., Hawley J.E., Pytkowicz R.M., 1973, Measurements of the apparent dissociation constants of carbonic acid in seawater at atmospheric pressure. Limnol. Oceanogr. 18, 897-907.

Minier C., Tutundjian R., Galgani F., Robert J.-M., 1998, Copper tolerance in Haslea ostrearia assessed by measurements of in vivo esterase activity. Mar. Environ. Res. 46, 579-582.

Moreau C., 1998, Des eaux souterraines salées en Baie de Bourgneuf pour la production de microalgues en aquaculture : l'azote ammoniacal, le fer et le manganèse dissous, causes de la variabilité de la fertilité potentielle pour trois diatomées-tests, Bull. Soc. Sci. Nat. Ouest de la France 20, 49-60.

Muller-Feuga A., 2000, The role of microalgae in aquaculture: situation and trends. J. Appl. Phycol. 12, 527-534.

Nassiri Y., 1995, Approche par microscopie électronique à transmission analytique des mécanismes de toxicité et de bioaccumulation $\mathrm{du}$ cadmium et du cuivre chez Skeletonema costatum, Tetraselmis suecica et Crassostrea gigas, Thèse de doctorat, Université de Nantes.

Nassiri Y., Ginsburger-Vogel T., Mansot J.-L., Wery J., 1996, Effects of heavy metals on Tetraselmis suecica: ultrastructural and energy-dispersive X-ray spectroscopic studies. Biol. Cell. 86, 151-160.

Ng T.Y.-T., Amiard-Triquet C., Rainbow P.S., Amiard J.C., Wang W.-X., 2005, Physico-chemical form of trace metals accumulated by phytoplankton and their assimilation by filter-feeding invertebrates. Mar. Ecol. Prog. Ser. 299, 179-191.

Nriagu J.O., Pacyna J.M., 1988, Quantitative Assessment of worldwide contamination of air, water and soils by trace metals. Nature 333, 134-139.

Nürnberg H.W., 1983, Investigations on heavy metal speciation in natural waters by voltammetric procedures. Fresenius Z. Anal. Chem. 316, 557-565.
Partridge G.J., 2002, Evaluating the suitability of saline groundwater from Lake Toolibin, Western Australia for culturing barramundi (Lates calcarifer), mulloway (Argyrosomus japonicus) and snapper (Pagrus auratus). Aquaculture Development Unit Challenger TAFE, Perth.

Perrein-Ettajani H., Amiard J.-C., Haure J., Renaud C., 1999, Effets des métaux (Ag, $\mathrm{Cd}, \mathrm{Cu}$ ) sur la composition biochimique et compartimentation de ces métaux chez deux microalgues Skeletonema costatum et Tetraselmis suecica. Can. J. Fish. Aquat. Sci. 56, 1757-1765.

Richards F.A., Thompson T.G., 1952, The estimation and characterization of plankton populations by pigment analyses. II. A spectrophotometric method for the estimation of plankton pigments. J. Mar. Res. 11, 156-172.

Robert J.-M., 1983, Fertilité des eaux des claires ostréicoles et verdissement : utilisation de l'azote par les diatomées dominantes, Thèse de Doctorat d'État es Sciences biologiques, Université de Nantes.

Robert J.-M., 1990, An example of development for aquaculture in France: the shellfish-culture polders in the Bay of Bourgneuf. Bull. Ecol. 21, 39-43.

Sauriau P.-G., Haure J., Baud J.-P., 1997, Sprinkling: a new method of distributing live algae food in marine coastal ponds used for Manila clam Tapes philippinarum (Adams \& Reeve) intensive culture. Aquac. Res. 28, 661-669.

Serrano A., Rivas J., Losada M., 1981, Nitrate and nitrite as in vivo quenchers of chlorophyll fluorescence in blue-green algae. Photosynth. Res. 2, 175-184.

Strickland J.D.H., Parsons T.R., 1972, A pratical handbook of seawater analysis. Bull. Fish. Res. Board Can. 167, 311pp.

Sunda W.G., Price N.M., Morel F. M.M., 2005, Trace metal ion buffers and their use in culture studies. In: Andersen R.A. (Ed.), Algal culturing techniques. Elsevier - Academic Press, Boston, pp 35-63.

Torres E., Cid A., Herrero C., Abalde J., 1998, Removal of cadmium ions by the marine diatom Phaeodactylum tricornutum Bohlin accumulation and long-term kinetics of uptake. Bioresour. Technol. 63, 213-220.

Turpin V., Robert J.M., Goulletquer P., 1999, Limiting nutrients of oyster pond seawaters in the Marennes-Oléron Région for Haslea ostrearia : applications to the mass production of the diatom in mesocosm experiments. Aquat. Living Resour. 12, 335-342.

Wang W.X., 2002, Interactions of trace metals and different marine food chains. Mar. Ecol. Prog. Ser. 243, 295-309.

Zhou X., Wangersky P.J., 1989, Production of copper-complexing organic ligands by the marine diatom Phaeodactylum tricornutum in a cage turbidostat. Mar. Chem. 26, 239-259. 